\author{
L.V. Kritskov ${ }^{1}$, M.A. Sadybekov ${ }^{2}$, A.M. Sarsenbi ${ }^{3}$ \\ ${ }^{1}$ M.V. Lomonosov Moscow State University, Russia; \\ ${ }^{2}$ Institute of Mathematics and Mathematical Modeling, Almaty, Kazakhstan; \\ ${ }^{3}$ M. Auezov South Kazakhstan State University, Shymkent, Kazakhstan \\ (E-mail: kritskov@cs.msu.su)
}

\title{
Nonlocal spectral problem for a second-order differential equation with an involution
}

For the spectral problem $-u^{\prime \prime}(x)+\alpha u^{\prime \prime}(-x)=\lambda u(x),-1<x<1$, with nonlocal boundary conditions $u(-1)=\beta u(1), u^{\prime}(-1)=u^{\prime}(1)$, where $\alpha \in(-1,1), \beta^{2} \neq 1$, we study the spectral properties. We show that if $r=\sqrt{(1-\alpha) /(1+\alpha)}$ is irrational, then the system of eigenfunctions is complete and minimal in $L_{2}(-1,1)$ but is not a basis. In the case of a rational number $r$, the root subspace of the problem consists of eigenvectors and an infinite number of associated vectors. In this case, we indicated a method for choosing associated functions that provides the system of root functions of the problem is an unconditional basis in $L_{2}(-1,1)$.

Keywords: ODE with involution, nonlocal boundary-value problem, spectral problem, basicity of root functions

\section{Introduction}

In the present paper, we carry out a complete spectral analysis of the problem

$$
\begin{gathered}
L u=-u^{\prime \prime}(x)+\alpha u^{\prime \prime}(-x),-1<x<1 ; \\
u^{\prime}(-1)=u^{\prime}(1), \quad u(-1)=\beta u(1),
\end{gathered}
$$

where the differential expression contains an involution transformation of the independent variable in the highest derivative and the boundary conditions are nonlocal.

Throughout the following, the parameter $\alpha$ in problem (1) is an arbitrary number in the interval $(-1,1)$. The case $\beta=1$ (when the boundary conditions of the problem are periodic) was investigated in [1]. The case when $\beta=-1$ leads to a degenerate problem. In this case, as it is easy to see, any number $\lambda$ is an eigenvalue. Therefore, in this paper we assume that $\beta$ is an arbitrary real number for which $\beta^{2} \neq 1$.

If $\alpha=\beta=0$, then problem (1) becomes the well-known nonlocal problem of the Samarskii- Ionkin type [2], which is an example of a nonself-adjoint problem whose set of root functions contains, in addition to eigenfunctions, infinitely many associated functions. Il'in [3] dubbed such problems essentially nonselfadjoint and pointed out their typical instability both under the choice of associated functions and under small perturbations of the operator. For details, see [4] and also [5-9].

We show that problem (1) has all specific features of essentially nonself-adjoint problems and that its spectral properties can change fundamentally under arbitrarily small variations of the parameter $\alpha$.

We note that the case $\beta=0$ was investigated in detail in [10] for the space $L_{2}$ and in [11] for the space $L_{p}$, $1<p<\infty$.

The main result of the present paper is stated in the following theorems.

Theorem 1. Let $r=\sqrt{(1-\alpha) /(1+\alpha)}$ be irrational. Then the system of root functions of problem (1) contains only eigenfunctions; moreover, it is complete and minimal in $L_{2}(-1,1)$ but is not a basis.

Theorem 2. Let $r=\sqrt{(1-\alpha) /(1+\alpha)}$ be rational. Then the spectrum of problem (1) splits into two sequences $\left\{\lambda_{n}\right\} \cup\left\{\lambda_{n}^{*}\right\}$. For each $\lambda=\lambda_{n}$, there exists only one eigenfunction, and for each $\lambda=\lambda_{n}^{*}$, there exists one eigenfunction and one associated function. The system of root functions is complete and minimal in $L_{2}(-1,1)$, and the associated functions can be chosen in such a way that the entire system is an unconditional basis in $L_{2}(-1,1)$.

Note that functional-differential equations similar to the equation in (1) were studied by numerous authors. The algebraic and analytic aspects of the theory of ordinary differential equations with involution were discussed 
in the monographs $[12,13]$. Spectral problems arising in connection with differential operators with involution were considered in [14-18] for first-order operators and in [19, 20] for second-order operators. Spectral problems for ordinary differential operators with non-strongly regular boundary conditions and their applications for parabolic problems were investigated in [21-25].

\section{Case of irrational $r$}

The problem adjoint to (1) has the form

$$
\begin{gathered}
L v(x)=-v^{\prime \prime}(x)+\alpha v^{\prime \prime}(-x),-1<x<1 \\
(\alpha-\beta) v^{\prime}(-1)=(\alpha \beta-1) v^{\prime}(1), \quad v(-1)=v(1) .
\end{gathered}
$$

By a straightforward computation, one can readily show that the spectra of problems (1) and (2) coincide and

$$
\sigma(L)=\left\{0 ;(1 \pm \alpha) \pi^{2} n^{2} \mid n \in \mathbb{N}\right\}
$$

while the eigenfunctions of the direct problem (1) have the form (here and in what follows, $\mu$ is the arithmetic value of the root $\sqrt{\lambda}$ )

$$
\begin{gathered}
\mu_{0}=0: u_{0}=(1-\beta) x+1+\beta ; \\
\mu^{\prime}{ }_{l}=\sqrt{1+\alpha} \pi l: u_{l}^{(1)}(x)=\sin (\pi l x), \quad l \in \mathbb{N} ; \\
\mu_{k}^{\prime \prime}=\sqrt{1-\alpha} \pi k: u_{k}^{(2)}(x)=(1+\beta) \sin (\pi r k) \cos (\pi k x)+(1-\beta) \cos (\pi k) \sin (\pi r k x), \quad k \in \mathbb{N}
\end{gathered}
$$

and eigenfunctions of the adjoint problem (2) have the form

$$
\begin{gathered}
\mu_{0}=0: v_{0}(x)=1 \\
\mu^{\prime \prime}{ }_{k}=\sqrt{1-\alpha} \pi k: v_{k}^{(2)}(x)=\cos (\pi k x), \quad k \in \mathbb{N} \\
\mu_{l}^{\prime}=\sqrt{1+\alpha} \pi l: v_{l}^{(1)}(x)=(1+\beta) r \sin \frac{\pi l}{r} \sin (\pi l x)+(1-\beta) \cos (\pi l) \cos \frac{\pi l x}{r}, \quad l \in \mathbb{N} .
\end{gathered}
$$

Lemma 1. Let $r$ be irrational. Then each of systems (4) and (5) is complete and minimal in $L_{2}(-1,1)$.

Proof. Let us carry out the proof, say, for system (4). Consider an arbitrary function $f(x) \in L_{2}(-1,1)$ orthogonal to all functions of system (4). Since it is orthogonal to the functions $u_{l}^{(1)}(x), l \in \mathbb{N}$, we see that it coincides almost everywhere with an even function. Thus,

$$
0=\int_{-1}^{1} f(x) u_{k}^{(2)}(x) d x=(1+\beta) \sin (\pi r k) \int_{-1}^{1} f(x) \cos (\pi k x) d x .
$$

Since $r \notin Q$ and $(1+\beta) \neq 0$, it follows that the function $f(x)$ is orthogonal to the functions $\cos (\pi k x), k \in \mathbb{N}$, and hence $f(x)=$ const almost everywhere on $[-1,1]$. Finally, from the relation $\left(f, u_{0}\right)=0$, since $(1+\beta) \neq 0$, it follows that $f(x)=0$ almost everywhere on $[-1,1]$.

Since systems (4) and (5) are complete, it follows that they are closed in $L_{2}(-1,1)$; and since they correspond to mutually adjoint problems, we find that they are minimal. The proof of the lemma is complete.

Let us modify the eigenfunctions so as to ensure that systems (4) and (5) form a biorthonormal pair in $L_{2}(-1,1)$. Since

$$
\left(u_{0}, v_{0}\right)=2(1+\beta),\left(u_{l}^{(1)}, v_{l}^{(1)}\right)=(1+\beta) r \sin \frac{\pi l}{r},\left(u_{l}^{(2)}, v_{l}^{(2)}\right)=(1+\beta) \sin (\pi r k),
$$

it follows that the modification should have the form

$$
\tilde{u}_{0}(x)=\frac{1-\beta}{1+\beta} x+1, \tilde{v}_{0}(x)=\frac{1}{2}
$$




$$
\begin{gathered}
\tilde{u}_{l}^{(1)}(x)=\sin (\pi l x), \quad \tilde{v}_{l}^{(1)}(x)=\sin (\pi l x)+\frac{1-\beta}{1+\beta} \frac{\cos (\pi l)}{r \sin \frac{\pi l}{r}} \cos \frac{\pi l x}{r} \\
\tilde{u}_{k}^{(2)}(x)=\cos (\pi k x)+\frac{1-\beta}{1+\beta} \frac{\cos (\pi k)}{\sin (\pi r k)} \sin (\pi r k x), \quad \tilde{v}_{k}^{(2)}(x)=\cos (\pi k x) .
\end{gathered}
$$

Let us compute the norms of these functions in $L_{2}(-1,1)$. We have

$$
\begin{gathered}
\left\|\tilde{u}_{l}^{(1)}\right\|=1, \quad\left\|\tilde{v}_{l}^{(1)}\right\|^{2}=1+\left(\frac{1-\beta}{1+\beta}\right)^{2}\left(r \sin \frac{\pi l}{r}\right)^{-2}\left(1+\frac{r}{2 \pi l} \sin \frac{2 \pi l}{r}\right) ; \\
\left\|\tilde{u}_{k}^{(2)}\right\|^{2}=1+\left(\frac{1-\beta}{1+\beta}\right)^{2}(\sin \pi r k)^{-2}\left(1+\frac{1}{2 \pi r k} \sin (2 \pi r k)\right), \quad\left\|\tilde{v}_{k}^{(2)}\right\|=1 .
\end{gathered}
$$

Lemma 2. Let $r$ be irrational. Then there exist sequences $\left\{l_{n}\right\}$ and $\left\{k_{n}\right\}$ such that $\left\|\tilde{v}_{l_{n}}^{(1)}\right\| \rightarrow \infty$ and $\left\|\tilde{u}_{k_{n}}^{(2)}\right\| \rightarrow \infty$, as $n \rightarrow \infty$.

Proof. By virtue of the theorem on the approximation of real numbers by rational fractions [26; 25], the inequalities

$$
\left|r-\frac{l}{s}\right|<\frac{1}{s^{2}}, \quad\left|\frac{1}{r}-\frac{k}{q}\right|<\frac{1}{q^{2}}
$$

have infinitely many solutions $l, k, s, q \in \mathbb{N}$. We denote these solutions by $l_{n}, k_{n}, s_{n}$ and $q_{n}$. Then from inequality (7) we have $\left|\frac{\pi l_{n}}{r}-\pi s_{n}\right|<\frac{\pi}{r s_{n}}$ and hence

$$
\sin ^{2} \frac{\pi l_{n}}{r}=\sin ^{2}\left(\frac{\pi l_{n}}{r}-\pi s_{n}\right)<\sin ^{2} \frac{\pi}{r s_{n}} .
$$

In a similar way, we obtain the inequalities $\left|\pi r k_{n}-\pi q_{n}\right|<\frac{\pi r}{q_{n}}$ and

$$
\sin ^{2}\left(\pi r k_{n}\right)<\sin ^{2} \frac{\pi r}{q_{n}}
$$

Therefore,

$$
\left\|\tilde{v}_{l_{n}}^{(1)}\right\|^{2}>1+\left(\frac{1-\beta}{1+\beta}\right)^{2} \frac{2}{3}\left(r \sin \frac{\pi}{r s_{n}}\right)^{-2},\left\|\tilde{u}_{k_{n}}^{(2)}\right\|^{2}>1+\left(\frac{1-\beta}{1+\beta}\right)^{2} \frac{2}{3}\left(r \sin \frac{\pi r}{q_{n}}\right)^{-2} .
$$

The proof of the lemma is complete, because the right-hand sides of these inequalities infinitely increase as $n \rightarrow \infty$.

Lemma 2 essentially completes the proof of Theorem 1, because it follows from the lemma that the considered biorthonormal pair of function of these systems does not satisfy the condition of uniform boundedness for the product of norms:

$$
\left\|\tilde{u}_{l}^{(1)}\right\| \cdot\left\|\tilde{v}_{l}^{(1)}\right\| \leq c_{1}, \quad\left\|\tilde{u}_{k}^{(2)}\right\| \cdot\left\|\tilde{v}_{k}^{(2)}\right\| \leq c_{2},
$$

which is necessary for the basis property $[27]$ in $L_{2}(-1,1)$.

\section{Case of rational $r$}

Let $r=\sqrt{(1-\alpha) /(1+\alpha)}$ be a rational number, which can be represented by an irreducible fraction $r=\frac{m_{1}}{m_{2}}$ where $m_{1}, m_{2} \in \mathbb{N}$.

Then a merging effect is observed for the following points of the spectrum $\sigma(L)$

$$
\mu_{m_{1} n}^{\prime}=\mu_{m_{2} n}^{\prime \prime}, \quad n \in \mathbb{N} .
$$

We denote the sequence extracted in (9) by $\mu_{n}^{*}$ and note that the eigenfunctions corresponding to the eigenvalues $\lambda=\lambda_{n}^{*} \equiv\left(\mu_{n}^{*}\right)^{2}$ are linearly dependent,

$$
\begin{aligned}
& u_{m_{1} n}^{(1)}(x)=(-1)^{m_{2} n}(1-\beta)^{-1} u_{m_{2} n}^{(2)}(x)=\sin \left(\pi m_{1} n x\right) \equiv u_{n}^{*}(x) \\
& (-1)^{m_{1} n}(1-\beta)^{-1} v_{m_{1} n}^{(1)}(x)=v_{m_{2} n}^{(2)}(x)=\cos \left(\pi m_{2} n x\right) \equiv v_{n}^{*}(x) .
\end{aligned}
$$

Therefore, the systems of eigenfunctions (4) and (5) become incomplete in $L_{2}(-1,1)$. 
We supplement the eigenfunctions corresponding to $\lambda=\lambda_{n}^{*}$ by associated functions, that is, the solutions of the inhomogeneous problems

$$
\begin{gathered}
L u(x)=\lambda_{n}^{*} u(x)+u_{n}^{*}(x), \quad-1<x<1 ; \\
u^{\prime}(-1)=u^{\prime}(1), \quad u(-1)=\beta u(1) ; \\
L v(x)=\lambda_{n}^{*} v(x)+v_{n}^{*}(x), \quad-1<x<1 ; \\
(\alpha-\beta) v^{\prime}(-1)=(\alpha \beta-1) v^{\prime}(1), \quad v(-1)=v(1) .
\end{gathered}
$$

By straightforward computations, we find the functions

$$
\begin{aligned}
& u_{n, 1}^{*}(x)=\left(2(1+\alpha) \pi m_{1} n\right)^{-1}\left[x \cos \left(\pi m_{1} n x\right)+\frac{1+\beta}{1-\beta}(-1)^{\left(m_{1}+m_{2}\right) n} \cos \left(\pi m_{2} n x\right)\right]+a_{n} u_{n}^{*}(x) ; \\
& v_{n, 1}^{*}(x)=\left(2(1-\alpha) \pi m_{2} n\right)^{-1}\left[-x \sin \left(\pi m_{2} n x\right)+\frac{1+\beta}{1-\beta} r(-1)^{\left(m_{1}+m_{2}\right) n} \sin \left(\pi m_{1} n x\right)\right]-a_{n} v_{n}^{*}(x),
\end{aligned}
$$

which are solutions of problem (10) and (11), respectively, for arbitrary $a_{n} \in \mathbb{R}$.

Note that if we substitute $u_{n, 1}^{*}(x)$ for $u_{n}^{*}(x)$ into the right-hand side of (10) and $v_{n, 1}^{*}(x)$ for $v_{n}^{*}(x)$ into (11), then problems (10) and (11) have no solutions. It follows that the corresponding problems have no associated functions of the second or any higher order.

Lemma 3. Let $r=m_{1} / m_{2}$ be rational. Then each of the systems of root functions obtained by the following procedures is complete and minimal in $L_{2}(-1,1)$ :

- for problem (1), one takes the union of the eigenfunctions (4) corresponding to $\lambda \neq \lambda_{n}^{*}$, the eigenfunctions $u_{n}^{*}(x)$, and the associated functions $u_{n, 1}^{*}(x), n \in \mathbb{N}$;

- for problem (2), one takes the union of the eigenfunctions (5) corresponding to $\lambda \neq \lambda_{n}^{*}$, the eigenfunctions $v_{n}^{*}(x)$, and the associated functions $v_{n, 1}^{*}(x), n \in \mathbb{N}$.

Proof. The proof is similar to that of Lemma 1. Consider the system of root functions of problem (1) and suppose that a function $f(x) \in L_{2}(-1,1)$ is orthogonal to all functions of that system.

Since the function $f(x)$ is orthogonal to all eigenfunctions $u_{l}^{(1)}(x), l \in \mathbb{N}$, we find that it coincides almost everywhere with an even function. In addition, the function $f(x)$ is orthogonal to all eigenfunctions $u_{k}^{(2)}(x), k \equiv 0$ $\left(\bmod m_{2}\right)$, and all associated functions $u_{n, 1}^{*}(x), n \in \mathbb{N}$. By virtue of its evenness, in this case, the function $f(x)$ is orthogonal to all functions $\cos (\pi k x), k \in \mathbb{N}$, as well. Therefore, it is equal almost everywhere to a constant, which, just as in Lemma 1, implies the assertion of the lemma. The proof of the lemma is complete.

Let us now modify the root functions of problem (4) and (5) so as to ensure that they form a biorthonormal pair.

If $\lambda \neq \lambda_{n}^{*}$, then the corresponding eigenfunctions satisfy the same relations $(6)$, where $l \equiv 0\left(\bmod m_{1}\right)$ and $k \equiv 0\left(\bmod m_{2}\right)$. Therefore, $l=l_{1} m_{1}+l_{2}$, where $l_{1}, l_{2} \in \mathbb{N}, 1 \leq l_{2} \leq m_{1}-1$, and the number $\frac{l}{r}=l_{1} m_{2}+l_{2} \frac{m_{2}}{m_{1}}$ is not an integer; consequently,

$$
\sin ^{2} \frac{\pi l}{r}=\sin ^{2}\left(\pi\left(\frac{l}{r}-l_{1} m_{2}\right)\right)=\sin ^{2}\left(\pi \frac{l_{2} m_{2}}{m_{1}}\right) \geq \sin ^{2} \frac{\pi}{m_{1}} .
$$

Likewise, we have $k=k_{1} m_{2}+k_{2}, k_{1}, k_{2} \in \mathbb{N}, 1 \leq k_{2} \leq m_{2}-1$, and the number $r k=k_{1} m_{1}+k_{2} \frac{m_{1}}{m_{2}}$ is not an integer; consequently,

$$
\sin ^{2}(\pi r k)=\sin ^{2}\left(\pi\left(r k-k_{1} m_{1}\right)\right) \sin ^{2}\left(\pi \frac{k_{2} m_{1}}{m_{2}}\right) \geq \sin ^{2} \frac{\pi}{m_{2}} .
$$

Consider the eigenvalues $\lambda=\lambda_{n}^{*}$. We have

$$
\left(u_{n}^{*}, v_{n}^{*}\right)=\left(u_{n, 1}^{*}, v_{n, 1}^{*}\right)=0, \quad\left(u_{n}^{*}, v_{n, 1}^{*}\right)=\left(u_{n, 1}^{*}, v_{n}^{*}\right)=\left(2(1+\alpha) \pi m_{1} n\right)^{-1} \frac{1+\beta}{1-\beta}(-1)^{\left(m_{1}+m_{2}\right) n} .
$$

Therefore, biorthonormal pairs in $L_{2}(-1,1)$ are formed by the function systems

$$
\begin{gathered}
\tilde{u}_{0}(x), \quad \tilde{u}_{l}^{(1)}(x), l \neq 0\left(\bmod m_{1}\right), \quad \tilde{u}_{k}^{(2)}(x), k \neq 0\left(\bmod m_{2}\right) ; \\
\tilde{u}_{n}^{*}(x)=\sin \left(\pi m_{1} n x\right), \quad \tilde{u}_{n, 1}^{*}(x)=u_{n, 1}^{*}(x), \quad n \in \mathbb{N},
\end{gathered}
$$


for problem (1) and

$$
\begin{gathered}
\tilde{v}_{0}(x), \quad \tilde{v}_{l}^{(1)}(x), l \neq 0\left(\bmod m_{1}\right), \quad \tilde{v}_{k}^{(2)}(x), k \neq 0\left(\bmod m_{2}\right) ; \\
\tilde{v}_{n}^{*}(x)=2(1+\alpha) \pi m_{1} n(-1)^{\left(m_{1}+m_{2}\right) n} \frac{1-\beta}{1+\beta} \cos \left(\pi m_{2} n x\right) ; \\
\tilde{v}_{n, 1}^{*}(x)=-r^{-1}(-1)^{\left(m_{1}+m_{2}\right) n} \frac{1-\beta}{1+\beta} x \sin \left(\pi m_{2} n x\right)+\sin \left(\pi m_{1} n x\right)-a_{n} \tilde{v}_{n}^{*}(x), \quad n \in \mathbb{N},
\end{gathered}
$$

for problem (2) with arbitrary constants $a_{n} \in \mathbb{R}$.

Let us evaluate and estimate the product of norms of root functions. By virtue of the relations presented before Lemma 2 and the estimates (14) and (15), the products of norms of the corresponding eigenfunctions are uniformly bounded for $\lambda \neq \lambda_{n}^{*}$. If $\lambda=\lambda_{n}^{*}$, then we have

$$
\begin{gathered}
\left\|\tilde{u}_{n}^{*}\right\|^{2}=1, \quad\left\|\tilde{v}_{n}^{*}\right\|^{2}=\left(2(1+\alpha) \pi m_{1} n \frac{1-\beta}{1+\beta}\right)^{2} ; \\
\left\|\tilde{u}_{n, 1}^{*}\right\|^{2}=\frac{(1 / 3)+\frac{1-\beta}{1+\beta}+\left(2 \pi^{2} m_{1}^{2} n^{2}\right)^{-1}}{\left(2(1+\alpha) \pi m_{1} n\right)^{2}}-\frac{a_{n} n^{-2}}{2(1+\alpha) \pi^{2} m_{1}^{2}}+a_{n}^{2} ; \\
\left\|\tilde{v}_{n, 1}^{*}\right\|^{2}=\frac{(1 / 3)-\left(2 \pi^{2} m_{2}^{2} n^{2}\right)^{-1}}{r^{2}}\left(\frac{1-\beta}{1+\beta}\right)^{2}+1+2(1+\alpha) \frac{1-\beta}{1+\beta} a_{n}+\left(2(1+\alpha) \pi m_{1}\right)^{2} a_{n}^{2} n^{2} .
\end{gathered}
$$

Therefore, each of the products $\left\|\tilde{u}_{n}^{*}\right\|^{2}\left\|\tilde{v}_{n, 1}^{*}\right\|^{2}$ and $\left\|\tilde{u}_{n, 1}^{*}\right\|^{2}\left\|\tilde{v}_{n}^{*}\right\|^{2}$ has the form

$$
c_{3}(n)+c_{4} a_{n}+c_{5} a_{n}^{2} n^{2},
$$

where $c_{4}, c_{5}>0$ are constants and $c_{3}(n)$ satisfies the inequality $0<c^{\prime}{ }_{3} \leq c_{3}(n) \leq c^{\prime \prime}{ }_{3}$ for all $n \in \mathbb{N}$.

Lemma 4. The products of $L_{2}$-norms of the respective root functions in the biorthonormal pair are uniformly bounded if and only if

$$
a_{n}=O\left(n^{-1}\right) \text { as } n \rightarrow \infty .
$$

Proof. Indeed, if $a_{n}=O(1)$, then (18) is uniformly bounded provided that $a_{n} n=O(1)$. If the sequence $a_{n}$ is not bounded, then (18) is equivalent to $c_{5} a_{n}^{2} n^{2}$ as $n \rightarrow \infty$ and hence is again uniformly bounded under condition (19). The proof of the lemma is complete.

Let us show that, in a sense, condition (19) is a rule for the selection of associated functions which provides the basis property of considered systems of root functions in $L_{2}(-1,1)$.

Lemma 5. If condition (19) is satisfied, then each of systems (16) and (17), after the normalization in $L_{2}(-1,1)$, satisfies a Bessel type inequality and hence forms an unconditional basis in $L_{2}(-1,1)$.

Proof. For example, consider system (16) of root functions of problem (1). If $\lambda \neq \lambda_{n}^{*}$, then the normalization gives the system

$$
\begin{gathered}
\sqrt{\frac{3}{2}}\left[3+\left(\frac{1-\beta}{1+\beta}\right)^{2}\right]^{-1 / 2}\left(1+\frac{1-\beta}{1+\beta} x\right), \sin (\pi l x) ; \\
\left\|\tilde{u}_{k}^{(2)}\right\|_{2}^{-1}\left(\cos (\pi k x)+\frac{1-\beta}{1+\beta} \frac{\cos (\pi k)}{\sin (\pi r k)} \sin \left(\pi \frac{m_{1}}{m_{2}} k x\right)\right) ;
\end{gathered}
$$

where $l \neq 0\left(\bmod m_{1}\right), k \neq 0\left(\bmod m_{2}\right)$, and, as was shown above, $1 \leq\left\|\tilde{u}_{k}^{(2)}\right\|_{2} \leq c_{6}$.

For $\lambda=\lambda_{n}^{*}$, we have

$$
\begin{gathered}
\frac{\tilde{u}_{n}^{*}(x)}{\left\|\tilde{u}_{n}^{*}\right\|}=\sin \left(\pi m_{1} n x\right) ; \\
\left\|\tilde{u}_{n, 1}^{*}\right\|^{-1} \tilde{u}_{n, 1}^{*}(x)=A_{n}^{(1)}\left[x \cos \left(\pi m_{1} n x\right)+\frac{1+\beta}{1-\beta}(-1)^{\left(m_{1}+m_{2}\right) n} \cos \left(\pi m_{2} n x\right)\right]+A_{n}^{(2)} \sin \left(\pi m_{1} n x\right),
\end{gathered}
$$

where $0<c_{7} \leq A_{n}^{(1)}, A_{n}^{(2)} \leq c_{8}, n \in \mathbb{N}$.

Thus, to justify the Bessel property, it suffices to prove the Bessel property of the following three systems $(n \in \mathbb{N}):$

$$
\sin (\pi n x), \quad \cos (\pi n x),
$$




$$
\begin{aligned}
& \cos \left(\pi \frac{m_{1}}{m_{2}} n x\right) ; \\
& x \cos \left(\pi m_{1} n x\right) .
\end{aligned}
$$

System (20) is orthonormal in $L_{2}(-1,1)$ and hence satisfies the Bessel type inequality with constant $B=1$. The Bessel property of system (22) follows from the Bessel property of system (20), because the factor $x$ is bounded. Finally, system (21) is a Bessel system by virtue of the following assertion.

Lemma 6. Let $\left\{\gamma_{k}\right\}$ be a sequence of complex numbers such that

$$
\sup _{k}\left|\operatorname{Im}\left(\gamma_{k}\right)\right|<\infty, \quad \sup _{t \geq 1} \sum_{k:\left|\operatorname{Re}\left(\gamma_{k}\right)-t\right| \leq 1} 1<\infty .
$$

Then each of the systems $\left\{\sin \left(\gamma_{k} x\right)\right\}$ and $\left\{\cos \left(\gamma_{k} x\right)\right\}$ is a Bessel system in $L_{2}(-1,1)$.

Proof. By virtue of the estimates (23), $\gamma_{k}=\pi n+\delta_{n k}$, where

$$
\sup _{n, k}\left|\operatorname{Im}\left(\delta_{n k}\right)\right|<\infty, \sup _{n} \sum_{k:\left|\operatorname{Re}\left(\delta_{n k}\right)\right| \leq 1} 1<\infty .
$$

Therefore,

$$
\begin{aligned}
& \int_{-1}^{1} f(x) \sin \left(\gamma_{k} x\right) d x=\cos \left(\delta_{n k}\right) \int_{-1}^{1} f(x) \sin (\pi n x) d x+\sin \left(\delta_{n k}\right) \int_{-1}^{1} f(x) \cos (\pi n x) d x+ \\
& +\delta_{n k} \int_{-1}^{1} \sin \left(\delta_{n k} x\right) \int_{-1}^{x} f(\xi) \sin (\pi n \xi) d \xi d x-\delta_{n k} \int_{-1}^{1} \cos \left(\delta_{n k} x\right) \int_{-1}^{x} f(\xi) \cos (\pi n \xi) d \xi d x,
\end{aligned}
$$

which implies a Bessel type inequality for the system $\left\{\sin \left(\gamma_{k} x\right)\right\}$.

System (21) satisfies condition (23), because

$$
\operatorname{Im}\left(\gamma_{k}\right)=0, \quad \sum_{k:\left|\operatorname{Re}\left(\gamma_{k}\right)-t\right| \leq 1} \leq 2 m_{2}+1 .
$$

The unconditional basis property of system (16) follows from the well-known Bari theorem [28]. The proof of the lemma is complete.

Theorem 2 is completely proved.

We note that using the proven basis property of the system of root functions in the case when the parameter $r$ is a rational number, the problems describing the process of heat propagation in a thin closed wire wrapped around a weakly permeable insulation can be considered by the method of separation of variables. Such problems with periodic boundary conditions with respect to the space variable were considered in [1].

This research is financially supported by a grants AP05131225 (L.V. Kritskov and A.M. Sarsenbi) and AP05133271 (M.A. Sadybekov) from the Science Committee from the Ministry of Science and Education of the Republic of Kazakhstan.

\section{References}

1 Sadybekov, M., Dildabek, G., \& Ivanova, M. (2018). On an inverse problem of reconstructing a heat conduction process from nonlocal data, Advances in Mathematical Physics, Art. ID 8301656, 1-8.

2 Ionkin, N.I. (1977). Solution of a Boundary-Value Problem in Heat Conduction with a Nonclassical Boundary Condition, Differential Equations, 13, 2, 204-211.

3 Il'in, V.A. (1994). Basis Property and Equiconvergence with the Trigonometric Series of Root Function Expansions and the Form of Boundary Conditions for a Nonself-Adjoint Differential Operator, Differential Equations, 30, 9, 1402-1413.

4 Il'in, V.A., \& Kritskov, L.V. (2003). Properties of Spectral Expansions Corresponding to Nonself-Adjoint Differential Operators, Journal of Mathematical Sciences, (NY), 116, 5, 3489-3550. 
5 Lomov, I.S. (2011). Nonsmooth Eigenfunctions in Problems of Mathematical Physics, Differential Equations, 47, 3, 355-362.

6 Belyantsev, O.V., \& Lomov, I.S. (2012). On the Basis Property of Eigenfunctions of a Singular SecondOrder Differential Operator, Differential Equations, 48, 8, 1174-1176.

7 Kerimov, N.B. (2013). On a Boundary Value Problem of N. I. Ionkin Type, Differential Equations, 49, $10,1233-1245$.

8 Makin, A.S. (2013). On a Two-Point Boundary Value Problem for the Sturm-Liouville Operator with a Nonclassical Asymptotics of the Spectrum, Differential Equations, 49, 5, 536-544.

9 Kurbanov, V.M., \& Safarov, R.A. (2010). On the Influence of the Potential on the Convergence Rate of Expansions in Root Functions of the Schredinger Operator, Differential Equations, 46, 8, 1077-1084.

10 Kritskov, L.V., \& Sarsenbi, A.M. (2015). Spectral properties of a nonlocal problem for the differential equation with involution, Differential Equations, 51, 8, 984-990.

11 Kritskov, L.V., \& Sarsenbi, A.M. (2015). Basicity in $L_{p}$ of root functions for differential equations with involution, Electronic Journal of Differential Equations, 278, 1-9.

12 Przeworska-Rolewicz, D. (1973). Equations with Transformed Argument. Algebraic Approach, Amsterdam - Warszawa.

13 Wiener, J. (1993). Generalized Solutions of Functional Differential Equations, Singapore - New Jersey London - Hong Kong.

14 Kurdyumov, V.P., \& Khromov, A.P. (2008). Riesz Bases Formed by Root Functions of a FunctionalDifferential Equation with a Reflection Operator, Differential Equations, 44, 2, 203-212.

15 Burlutskaya, M.Sh., \& Khromov, A.P. (2009). On a Theorem on the Equiconvergence on the Entire Interval for Functional-Differential Operators, Izv. Saratov. Univ. Mat. Mekh. Inform., 9, 4, Part 1, 3-10.

16 Burlutskaya, M.Sh., \& Khromov, A.P. (2011). Fourier Method in an Initial-Boundary Value Problem for a First-Order Partial Differential Equation with Involution, Comput. Math. Math. Phys., 51, 12, 2102-2114.

17 Kopzhassarova, A.A., Lukashov, A.L., \& Sarsenbi, A.M. (2012). Spectral Properties of Non-Self-Adjoint Perturbations for a Spectral Problem with Involution, Abstr. Appl. Anal., art. ID 590781.

18 Cabada, A., \& Tojo, F.A.F. (2014). Existence Results for a Linear Equation with Reflection, Non-Constant Coefficient and Periodic Boundary Conditions, J. Math. Anal. Appl., 412, 1, 529-546.

19 Sadybekov, M.A., \& Sarsenbi, A.M. (2012). Criterion for the Basis Property of the Eigenfunction System of a Multiple Differentiation Operator with an Involution, Differential Equations, 48, 8, 1112-1118.

20 Kopzhassarova, A.A., \& Sarsenbi, A.M. (2012). Basis Properties of Eigenfunctions of Second-Order Differential Operators with Involution, Abstr. Appl. Anal., art. ID 576843.

21 Sadybekov, M., Dildabek, G., \& Tengayeva, A. (2017). Constructing a Basis from Systems of Eigenfunctions of one not Strengthened Regular Boundary Value Problem, Filomat, 31, 4, 981-987.

22 Sadybekov, M.A., \& Imanbaev, N.S. (2017). A regular differential operator with perturbed boundary condition, Mathematical Notes, 101, 5-6, 878-887.

23 Sadybekov, M., Oralsyn, G., \& Ismailov, M. (2018). Determination of a time-dependent heat source under not strengthened regular boundary and integral overdetermination conditions, Filomat, 32, 3, 809-814.

24 Sadybekov, M., \& Oralsyn, G. (2017). Nonlocal initial boundary value problem for the time-fractional diffusion equation, Electronic Journal of Differential Equations, 201, 1-7.

25 Sadybekov, M.A., Dildabek, G., \& Ivanova, M.B. (2018). Spectral properties of a Frankl type problem for parabolic-hyperbolic equations, Electronic Journal of Differential Equations, 65, 1-11.

26 Shidlovskii, A.B. (1987). Transcendental Numbers. Moscow: Nauka.

27 Mil'man, V.D. (1970). Geometric Theory of Banach Spaces. Part I: The Theory of Basis and Minimal Systems, Russian Math. Surveys, 25, 3, 111-170.

28 Bari, N.K. (1951). Biorthogonal Systems and Bases in Hilbert Space, Moskov. Gos. Univ. Uch. Zap. Matematika, 148, 69-107. 
Л.В. Крицков, М.А. Садыбеков, Ә.М. Сәрсенбі

\section{Инволюциясы бар екінші ретті дифференциалды теңдеу үшін локалдық емес шеттік есеп}

Шеттік шарттары $u(-1)=\beta u(1), u^{\prime}(-1)=u^{\prime}(1), \beta^{2} \neq 1$, локалдық емес мынадай спектралдық есептің $-u^{\prime \prime}(x)+\alpha u^{\prime \prime}(-x)=\lambda u(x),-1<x<1, \alpha \in(-1,1)$, спектралдық қасиеттері зерттелді. Егер $r=\sqrt{(1-\alpha) /(1+\alpha)}$ иррационал сан болса, онда есептің меншікті функциялары толық және минималды жүйе құрайды, алайда базис емес. Осы тұжырым дәлелденген. Егер $r$ рационал сан болса, онда есептің ақырсыз қосымша алынған функциялары бар. Бұл жағдайда қосымша алынған функцияларды таңдап алу жолдары келтірілген. Және таңдап алынған түпкілікті функциялар жүйесі $L_{2}(-1,1)$ кеңістігінде базис құрайтыны көрсетілген.

Kiлm сөздер: инволюциясы бар жай дифференциалды теңдеулер, локалдық емес шеттік есеп, спектралдық есеп, базис, түпкілікті функциялар.

\section{Л.В. Крицков, М.А. Садыбеков, А.М. Сарсенби}

\section{Нелокальная краевая задача для дифференциального уравнения второго порядка с инволюцией}

В статье изучены спектральные свойства для спектральной задачи $-u^{\prime \prime}(x)+\alpha u^{\prime \prime}(-x)=\lambda u(x)$, $-1<x<1$, с нелокальными граничными условиями $u(-1)=\beta u(1), u^{\prime}(-1)=u^{\prime}(1)$, где $\alpha \in(-1,1), \beta^{2} \neq 1$. Показано, что если $r=\sqrt{(1-\alpha) /(1+\alpha)}$ иррационально, то система собственных функций полна и минимальна в $L_{2}(-1,1)$, но не образует базиса. В случае рационального числа $r$ корневое подпространство задачи состоит из собственных векторов и бесконечного числа присоединенных векторов. В этом случае указан метод выбора присоединенных функций, при котором система корневых функций задачи является безусловным базисом в $L_{2}(-1,1)$.

Ключевые слова: ОДУ с инволюцией, нелокальная краевая задача, спектральная задача, базисность корневых функций. 